\title{
Faktor-Faktor Yang Mempengaruhi Tuberculosis Multidrug Resistance (TB MDR)
}

\author{
Trivianto G. Bawonte, ${ }^{1}$ Christi D. Mambo, ${ }^{2}$ Angelina S. R. Masengi ${ }^{2}$
}

\author{
${ }^{1}$ Program Studi Pendidikan Dokter Fakultas Kedokteran Universitas Sam Ratulangi \\ Manado, Indonesia \\ ${ }^{2}$ Bagian Farmakologi Klinik dan Terapi Fakultas Kedokteran Universitas Sam Ratulangi \\ Manado, Indonesia \\ Email: trivianto.gilbert@gmail.com
}

\begin{abstract}
Multidrug Resistance Tuberculosis (MDR TB) is Mycobacterium tuberculosis resistance to the first line of antituberculosis drugs are rifampicin and isoniazid. Globally, in 2017 there were around 558.000 new cases (range, 483.000-639.000) resistant TB rifampicin (TB RR), nearly half of which were in three counties, India (24\%), China (13\%), and Rusia $(10 \%)$. WHO estimates that there are 23.000 cases of MDR/RR in Indonesia. In 2017, there were 442.000 TB cases recorded in the program, of which an estimated 8.600-15.000 MDR/RR TB cases. The research to determine the factors that influence Multidrug Resistance Tuberculosis (MDR TB).this type of research is in the form of literature review with design of case control study and cross sectional study. The results showed that the risk factors were proven to influence the occurrence (MDR TB). The conclusion from 15 articles reviewed, it shows that age, gender, treatment irregularity and medication adherence are the most influencing factors for TB MDR.
\end{abstract}

Keywords: Factors, TB MDR, multidrug resistance tuberculosis

\begin{abstract}
Abstrak: Tuberculosis Multidrug Resistance (TB MDR) merupakan resistensi Mycobacterium tuberculosis terhadap jenis Obat Anti Tuberkulosis (OAT) lini pertama yaitu rifampisin dan isoniazid. Di tingkat global, di tahun 2017 terdapat sekitar 558.000 kasus baru (rentang, 483.000 - 639.000) TB rifampisin (TB RR) resistan di mana hampir separuhnya ada di tiga negara yaitu India (24\%), China (13\%), dan Rusia (10\%). WHO memperkirakan ada 23.000 kasus MDR/RR di Indonesia. Pada tahun 2017 kasus TB yang tercatat di program ada sejumlah 442.000 kasus yang mana dari kasus tersebut diperkirakan ada 8.600-15.000 MDR/RR TB. Penelitian ini bertujuan untuk mengetahui faktor-faktor yang mempengaruhi Tuberculosis Multidrug Resistance (TB MDR). Jenis penelitian ini berbentuk literature Review dengan rancangan case control study dan cross sectional study. Hasil penelitian ini menunjukkan bahwa faktor risiko terbukti mempengaruhi terjadinya (TB MDR). simpulan dari 15 artikel yang di review, menunjukkan bahwa usia, jenis kelamin, ketidakteraturan berobat, dan kepatuhan minum obat merupakan faktor yang paling mempengaruhi terjadinyaTB MDR.
\end{abstract}

Kata Kunci : Faktor - faktor, TB MDR, factors, multidrug tuberculosis

\section{PENDAHULUAN}

Tuberculosis Multidrug Resistance (TB MDR) merupakan resistensi Mycobacterium tuberculosis terhadap jenis Obat Anti Tuberkulosis (OAT) lini pertama yaitu rifampisin dan isoniazid. WHO 2013 melaporkan ada 450.000 kasus TB MDR di dunia tahun 2012, diperkirakan sekitar 4.000 kasus setiap tahun. Indonesia termasuk salah satu negara dengan kejadian TB MDR yang tertinggi di dunia. Di Indonesia dilaporkan ada 6.900 kasus di tahun 2012, 5.900 merupakan kasus TB MDR baru dan 1.000 telah mendapatkan pengobatan. ${ }^{1}$ 
Di tingkat global, di tahun 2017 terdapat sekitar 558.000 kasus baru (rentang, 483.000 - 639.000) TB rifampisin (TB RR) resistan di mana hampir separuhnya ada di tiga negara yaitu India (24\%), China (13\%), dan Rusia $(10 \%){ }^{2}$ dan pada tahun 2018 terjadi peningkatan kasus TB di India (27\%) dan China (14\%) sedangkan di Rusia terjadi penurunan (9\%). Di antara kasus TB RR, diperkirakan $82 \%$ kasus tersebut adalah TB MDR. Secara global, 3,6\% kasus TB baru dan $17 \%$ kasus TB pengobatan ulang merupakan kasus TB MDR/RR, dengan proporsi tertinggi ( $>50 \%$ pada kasus yang diobati sebelumnya). ${ }^{3}$

World Health Organization (WHO) memperkirakan ada 23.000 kasus MDR/RR di Indonesia. Pada tahun 2017 kasus TB yang tercatat di program ada sejumlah 442.000 kasus yang mana dari kasus tersebut diperkirakan ada 8.600-15.000 MDR/RR TB, (perkiraan 2,4\% dari kasus baru dan $13 \%$ dari pasien TB yang diobati sebelumnya), tetapi cakupan yang diobati baru sekitar 27,36\%. ${ }^{2}$ Pada tahun 2005 di poli paru Rumah Sakit Persahabatan, penderita tuberkulosis paru sebanyak 264 orang dengan TB MDR sebanyak 12 orang $(4,5 \%)$, pengamatan yang sama juga dilakukan oleh Munir dkk di Rumah Sakit Persahabatan selama 3 tahun (2005-2007) terdapat 554 pasien TB MDR dari 3727 pasien TB dalam kurun waktu tersebut dan kasus TB MDR di RSUD Arifin Achmad provinsi Riau berjumlah 24 pasien positif TB MDR dari 104 pasien suspek TB MDR bulan April 2013 sampai Juni 2014. ${ }^{1}$

Kejadian TB MDR tinggi di usia produktif berkisar 25-34 tahun. TB MDR sering dijumpai pada laki-laki dibandingkan dengan perempuan, hal ini juga ditunjang dengan penelitian Munir dkk yaitu jumlah kasus TB MDR sebanyak 53 orang (52,5\%), berdasarkan tingkat Pendidikan menengah terdapat kasus sebanyak 24 orang $(48 \%)$ dan berdasarkan pekerjaan wiraswasta berjumlah 16 orang (32\%). ${ }^{1}$

Jenis resistensi TB MDR lebih banyak resistensi terhadap rifampisin dan isoniazid dengan jumlah $51,4 \%$, pengobatan TB MDR menyatakan sebanyak $26,9 \%$ pasien menggunakan 3 jenis obat oral dan 1 injeksi. Beberapa penyebab resistensi terhadap OAT yaitu penggunaan obat yang tidak adekuat, pemakaian obat yang tidak teratur dan kurang pengetahuan tentang penyakit TB. ${ }^{1}$ Oleh dari itu, Tuberculosis Multidrug Resistance (TB MDR) menjadi masalah serius yang dihadapi sekarang di dunia maupun di Indonesia. Maka, berdasarkan latar belakang tersebut, peneliti tertarik untuk melakukan penelitian literature review untuk membahas dan menelaah berbagai informasi mengenai faktor-faktor yang mempengaruhi Tuberculosis Multidrug Resistance (TB MDR).

\section{METODE PENELITIAN}

Penelitian ini berbentuk literature review.. Data penelitian yang digunakan adalah literatur-literatur yang diambil dari tiga database yaitu Google Scholar, PubMed, dan Clinical Key. Kata kunci yang digunakan dalam pencarian literatur yaitu "Faktor-faktor" DAN "TB MDR" untuk pencarian di Google Scholar, dan "factors" AND “TB MDR" untuk pencarian di PubMed dan ClinicalKey. Kriteria Inklusi dalam peneltiian ini adalah populasi komunitas yang menderita Tuberculosis Multidrug Resistance (TB MDR), jenis penelitian cross-sectional studies dan case control studies. Tahun publikasi 2010-2020 serta berbahasa Indonesia dan Inggris.

Berdasarkan hasil pencarian literatur, didapatkan berdasarkan kata kunci dari tiga database berjumlah 519 dari Google Scholar, 153 dari PubMed, dan 679 dari ClinicalKey $(\mathrm{n}=1351)$ kemudian disaring kembali berdasarkan judul yang sesuai dengan topik literature review didapatkan 132 dari PubMed ( $\mathrm{n}=132)$, kemudian disaring kembali berdasarkan abstrak sesuai dengan kriteria inklusi didapatkan $(n=15)$ 
Tabel 1. Analisis Literatur

\begin{tabular}{lll}
\hline No & \multicolumn{1}{c}{ Penulis } & \multicolumn{1}{c}{ Informasi Utama } \\
\hline 1 & Sarwani & Hasil penelitian menunjukkan bahwa faktor risiko yang terbukti \\
& et al., 2012 & berpengaruh terhadap kejadian Multi Drug Resistant (TB MDR) yaitu \\
& & motivasi penderita yang rendah OR $=4,2 \quad(\mathrm{CI}=1,478-11,94)$ dan \\
& & ketidakteraturan berobat OR=2,3 (CI=1,3810,28).
\end{tabular}

2 Maria, $2015^{5}$ Hasil penelitian menunjukkan variabel kepatuhan minum obat yang tidak patuh terhadap minum obat sebanyak 28 (51,9\%) dengan nilai signifikansi $0,000 \leq 0,05$ dan berisiko terjadinya TB MDR sebesar 31.909. Sedangkan variabel jenis kelamin terbesar pada penderita TB Paru adalah laki-laki sebanyak $38(70,4 \%)$ dengan nilai signifikansi $0,000 \leq 0,05$ dan berisiko terjadinya TB MDR sebesar 14.469. Dan variabel riwayat merokok menunjukkan yang memiliki riwayat merokok sebanyak $30(55,6 \%)$ dengan nilai signifikansi $0,000 \leq 0,05$ dan berisiko terjadinya TB MDR sebesar 10.134. Faktor yang dominan beresiko terjadinya TB MDR adalah kepatuhan minum obat dengan score sebesar 31,909 , artinya bahwa orang yang memiliki ketidakpatuhan minum obat terhadap resiko terjadinya TB MDR 31,909 kali terjadi resiko TB MDR di wilayah kerja Kota Madiun

3 Widiastuti Hasil analisis menunjukkan tidak ada hubungan yang bermakna antara et al., $2017^{6}$ usia, jenis kelamin, pengobatan TB sebelumnya, merokok, kontak dengan pasien TB MDR, dan status HIV AIDS dengan kejadian TB MDR di RSUD Dr. Sardjito Yogyakarta (p value > 0,05).

4 Nunkaidah et Analisis bivariat menunjukan bahwa variabel usia, jenis kelamin dan al., $2017^{7}$ indeks massa tubuh berhubungan dengan risiko terjadinya TB MDR

5 Maharjan et Faktor yang berhubungan dengan TB MDR adalah jenis kelamin al., $2017^{8}$ perempuan. Sedangkan usia, riwayat TB yang diobati sebelumnya, ras, tempat tinggal di daerah perkotaan tidak terkait dengan TB MDR

6 Workicho et Usia responden (odds ratio yang disesuaikan [AOR] $=7$; interval al., $2017^{9}$ kepercayaan $95 \%$ [CI]: 2,6-24,5), tinggal di rumah tangga dengan hanya satu ruangan $(\mathrm{AOR}=5 ; 95 \% \mathrm{CI}: 1,68-15,38)$, riwayat pengobatan sebelumnya $(\mathrm{AOR}=21 ; 95 \% \mathrm{CI}: 17,8-28)$ dan terinfeksi HIV $(\mathrm{AOR}=$ 3,$1 ; 95 \%$ CI: 1,02-9,4) ditemukan sebagai prediktor independen TB MDR.

7 Budi Karakteristik rumah merupakan variabel yang berperan dalam et al., $2018^{10}$ penyebaran penyakit Tuberculosis dan kepadatan hunian merupakan faktor dominan kejadian penyakit tersebut

8 Stosic et al., Teridentifikasi enam faktor risiko independen yang signifikan untuk $2018^{11}$

terjadinya TB MDR sebagai berikut: pendapatan bulanan keluarga (rasio Odds $(\mathrm{OR})=3,71$; Interval Keyakinan 95\% $(\mathrm{CI})=1,22-11,28)$, tidak berobat $(\mathrm{OR}=3.33 ; 95 \% \mathrm{CI}=1.14-9.09)$, stigma terkait dengan $\mathrm{TB}$ $(\mathrm{OR}=2.97 ; 95 \% \mathrm{CI}=1.18-7.45)$, perasaan sedih subjektif $(\mathrm{OR}=4.05$; $95 \% \mathrm{CI}=1.69-9.70)$, penggunaan obat penenang $(\mathrm{OR}=2.79 ; 95 \% \mathrm{CI}=$ 1.02-7.65) dan penyakit paru obstruktif kronik $(\mathrm{OR}=4.51 ; 95 \% \mathrm{CI}=$ 1.07-18.96).

9 Demile Dengan menggunakan analisis bivariat, riwayat kontak TB merupakan et al., $2018^{12}$ prediktor kuat TB MDR. Selain itu, infeksi human immunodeficiency virus (HIV) juga merupakan faktor yang signifikan (OR $=14,6 ; 95 \% \mathrm{CI}$ $=2,3-92,1 ; p=0,004)$. Namun, jenis kelamin, usia dan indeks massa tubuh bukan merupakan faktor terkait untuk TB MDR. 
10 Janan, $2019^{13}$ Hasil penelitian menunjukkan bahwa faktor-faktor risiko yang berpengaruh terhadap peningkatan prevalensi kejadian TB MDR di Kabupaten Brebes Tahun 2011-2017 adalah kepatuhan minum obat (OR 6,7; 95\%CI 2,2- 19,7), Riwayat pengobatan TB sebelumnya (OR 5,3; 95\%CI 1,2-14,1), dan kesesuaian dosis/obat (OR 5,2; 95\%CI 1,2-22,8).

11 Ginanjar $e t$ Hasil penelitian menunjukkan bahwa faktor yang berhubungan dengan al., $2019^{14}$ kejadian TB MDR adalah faktor psikososial OR 0,049 (95\% CI: 0,0070,351) dan pendidikan OR 0,072 (95\% CI: 0,013-0,407).

12 Wahyuni, Hasil penelitian menunjukkan bahwa motivasi penderita $(\mathrm{OR}=5,342$; $2019^{15}$ $95 \% \mathrm{CI}=1,526-18,697)$, riwayat pengobatan sebelumnya $(\mathrm{OR}=31,360$; $95 \% \mathrm{CI}=8,165-120,453)$, kepatuhan minum obat $(\mathrm{OR}=6,5 ; 95 \% \mathrm{CI}=1,64-$ 25,759), lama pengobatan TB $(\mathrm{OR}=4,457 ; 95 \% \mathrm{CI}=2,756-239,939)$, dan status efek samping obat $(\mathrm{OR}=5,333 ; \quad 95 \% \mathrm{CI}=1,514-13,123)$ berhubungan dengan kejadian TB MDR di puskesmas Kota Semarang. Usia responden, jenis kelamin, tingkat pendidikan, status pekerjaan, tingkat pendapatan, status merokok, peran pengawas menelan obat (PMO), riwayat status gizi, dan jarak rumah ke fasilitas pelayanan kesehatan tidak berhubungan dengan kejadian TB MDR di puskesmas Kota Semarang. Faktor yang paling dominan dengan kejadian TB MDR adalah riwayat pengobatan sebelumnya.

13 Baya Kami menemukan bahwa usia $\leq 40$ tahun $(\mathrm{OR}=2.56 .95 \%$ CI: 1.44et al., 2019 4.55 ), pengobatan TB sebelumnya (OR $=3.25$, 95\% CI: 1.44-7.30), kegagalan pengobatan $\mathrm{TB}(\mathrm{OR}=3.82,95 \% \mathrm{CI} 1.82-7.79)$, dan riwayat kontak dengan pasien $\mathrm{TB}(\mathrm{OR}=2.48,95 \% \mathrm{CI}$ : 1.11-5.50) secara signifikan terkait dengan konfirmasi penyakit TB MDR. HIV bukan merupakan faktor risiko TB MDR (OR = 0,88, CI 95\%: 0,34-1,94).

14 Mashidayanti Hasil pada penelitian ini menunjukkan bahwa faktor risiko yang terbukti et al., $2020^{17}$ berpengaruh pada kejadian TB MDR adalah keteraturan minum obat (pvalue $<0,05)$.

15 Nurdin, Faktor yang menyebabkan kejadian TB MDR adalah pendidikan rendah, $2020^{18} \quad$ riwayat penyakit TB, hasil pengobatan TB yang gagal, riwayat putus pengobatan, penderita TB dengan diabetes melitus, dan penderita TB yang sulit mengakses fasilitas kesehatan.

\section{HASIL PENELITIAN}

Setelah melalui tahap seleksi studi, didapatkan 15 literatur yang memenuhi kriteria inklusi dan eksklusi dari 9 penelitian cross sectional study dan 6 penelitian case control study. Tahap seleksi studi tersebut menggunakan kata kunci tertentu yang sesuai dengan topik dan pembahasan yang diinginkan oleh peneliti, sehingga dapat menjawab pertanyaan yang ada pada rumusan masalah penelitian ini.

\section{BAHASAN}

Hasil screening artikel menunjukkan terdapat 15 laporan penelitian yang dapat digunakan untuk menjawab rumusan masalah penelitian ini. Sebanyak 10 laporan penelitian berasal dari Indonesia, sementara 5 penelitian berasal dari berbagai negara berkembang lain. Pembeda ini perlu dilakukan karena faktor lingkungan memiliki peranan penting dalam patogenesis tuberkulosis. Berbagai kondisi telah diidentifikasi sebagai faktor risiko terjadinya TB MDR, mulai dari faktor individu sampai dengan faktor tempat tinggal.

Faktor individu yang banyak diteliti adalah karakteristik subjek penelitian. Didapatkan 6 artikel penelitian yang meneliti pengaruh karakteristik individu terhadap kejadian TB MDR. Penelitian 
yang dilakukan oleh Nunkaidah (2017) mendapati bahwa usia, jenis kelamin, dan Indeks Massa Tubuh (IMT) berhubungan dengan kejadian TB MDR Penderita dengan usia produktif umumnya memiliki aktivitas yang cukup tinggi sehari-hari sehingga kadang-kadang terlupakan untuk minum -obat secara teratur. Jenis kelamin laki-laki kemungkinan karena prevalensi penyakit TB MDR lebih banyak pada lakilaki dan laki-laki lebih berat beban kerjanya, kurang istirahat, gaya hidup yang tidak sehat seperti merokok dan minum alkohol serta adanya perbedaan aktivitas keluar rumah terutama untuk bekerja, dan paparan polusi udara, sedangkan (IMT) yang kurang atau buruk berkaitan dengan status gizi yang kurang, maka reaksi kekebalan tubuh juga akan menurun sehingga kemampuan tubuh dalam mempertahankan diri terhadap infeksi juga menurun, ini juga berhubungan dengan jika seseorang memiliki infeksi kronis maka status gizi akan menurun karena itu daya tahan tubuh juga akan ikut menurun. ${ }^{7}$ Hasil ini juga didukung oleh penelitian Maria (2015) yang juga mendapati bahwa jenis kelamin laki-laki merupakan salah satu faktor risiko terjadinya TB $\mathrm{MDR}^{5}$ Penelitian yang dilakukan oleh Nurdin (2020) bahwa dengan tingkat pendidikan dasar mempunyai risiko terjadinya TB MDR 13 kali lebih besar dibandingkan dengan yang mempunyai tingkat pendidikan tinggi, ini kemungkinan karena pengetahuan yang rendah sulit untuk mendapatkan informasi untuk memahami tentang pelayanan dan pengobatan TB MDR. $^{18}$ dan Ginanjar (2019) juga mendapati bahwa tingkat pendidikan yang rendah merupakan salah satu faktor risiko terjadinya TB MDR. ${ }^{14}$

Hasil tersebut di atas berlawanan dengan dua penelitian, yaitu penelitian Widiastuti (2017) dan penelitian Wahyuni (2019). Penelitian Widiastuti (2017) mendapati bahwa tidak terdapat hubungan yang bermakna antara usia dan jenis kelamin dengan kejadian TB MDR, hal ini kemungkinan karena jumlah sampel yang sedikit serta menggunakan rumus, persentase antara kelompok kontrol dan kelompok kasus pada semua faktor risiko mempunyai selisih yang sangat kecil. ${ }^{6}$ Sementara penelitian Wahyuni (2019) mendapati bahwa usia, jenis kelamin, tingkat pendidikan, status pekerjaan, tingkat pendapatan, status gizi, dan jarak rumah ke fasilitas pelayanan kesehatan tidak berhubungan dengan kejadian TB MDR. Perbedaan ini diduga disebabkan perbedaan lokasi penelitian, sehingga perilaku masyarakat di lokasi penelitian juga mempengaruhi hasil dari empat penelitian tersebut. ${ }^{15}$

Penelitian yang dilakukan oleh Budi (2018) mendapati bahwa terdapat hubungan antara riwayat TB MDR anggota keluarga dan kemudahan akses informasi dengan kejadian TB MDR. Penelitian tersebut juga menyebutkan bahwa individu yang memiliki anggota keluarga mengalami TB MDR atau tidak dapat mengakses informasi dengan baik akan memiliki risiko 2,49 kali lipat lebih besar untuk mengalami TB MDR, kemungkinan karena penderita mempunyai anggota keluarga yang serumah sehingga penyebaran dapat terjadi dari satu ke yang lainnya. Sedangkan akses informasi yang kurang dapat terjadi 2,4 kali terkena TB MDR, ini disebabkan karena kurangnya infromasi mengenai TB yang berhubungan dengan ketersediaan dan kemudahan dalam mengakses informasi yang tepat mengenai TB. ${ }^{10}$ Terkait penyakit yang pernah diderita sebelumnya, penelitian Nurdin (2020) mendapati bahwa riwayat menderita TB sebelumnya dan riwayat menderita diabetes melitus merupakan faktor risiko dari terjadinya TB MDR. Berhungan dengan DM, bahwa pasien TB dengan komorbid DM harus lebih banyak diberikan informasi dan komunikasi yang persuasif tentang pentingnya minum OAT secara teratur dan melakukan pemeriksaan kontrol gula darah agar tetap terkontrol, karena kontrol gula darah yang buruk dapat menyebabkan gangguan fungsi fagositosis, kemotaksis, reactive oxygen species (ROS) dan fungsi sel Thelper. Hal ini tentu dapat menurunkan imunitas pasien TB dan dapat 
meningkatkan kasus TB MDR. Penelitian tersebut juga mendapati bahwa penderita TB yang sulit mengakses fasilitas kesehatan akan lebih berisiko mengalami TB MD, ini karena akses fasilitas kesehatan yang jauh, sehingga penderita sulit untuk melakukan pengobatan. ${ }^{18}$. Sementara itu, penelitian Ginanjar (2019) mendapati bahwa kesehatan psikis juga merupakan salah satu faktor terjadinya TB MDR, karena ini berhubungan dengan sosial ekonomi dan dukungan sosial. Didapatkan bahwa kekhawatiran yang umum yaitu orang akan mengetahui bahwa penderita memiliki jenis TB yang buruk, tidak puas dengan dipisahkan dari lingkungan sosial dan merindukan kebersamaan kembali dengan pasangan mereka. Kekhawatiran juga bahwa mereka mungkin telah menggunakan terlalu banyak obat, tidak senang karena tidak dapat, melakukan kegiatan sosial dan ekonomi. Kekhawatiran juga terjadi akibat penderita merasa didiskriminasi oleh anggota masyarakat dan sering menjadi terisolasi setelah teman dan kerabat menghentikan semua komunikasi ketika penderita didiagnosis dengan TB, walaupun sudah dinyatakan "tidak menular" oleh petugas kesehatan, teman-teman dan keluarga tetapi masih sering dipandang sebagai "tidak aman" dan menghindari interaksi dengan penderita. 14 Status HIV AIDS tidak terbukti sebagai faktor terjadinya TB MDR sebagaimana yang disebutkan dalam penelitian Widiastuti (2017), ini dikarenakan selisih persentase antara kasus dan kontrol sengat sedikit dan lebih banyak suspek TB MDR yang tidak dilakukan pemeriksaan HIV-AIDS ${ }^{6}$

Perilaku merokok sebagai faktor risiko terjadinya TB MDR telah diteliti dalam 3 penelitian. Penelitian yang dilakukan oleh Maria (2015) mendapati bahwa riwayat merokok merupakan salah satu faktor penting terjadinya TB MDR. Individu yang memiliki riwayat merokok akan memiliki risiko 10 kali lipat lebih besar untuk mengalami TB MDR daripada yang tidak memiliki riwayat merokok. ${ }^{5}$ Namun hasil berbeda ditunjukkan pada penelitian
Widiastuti (2017) bahwa merokok tidak ada berhubungan dengan kejadian TB MDR, dimungkinkan karena penderita menyembunyikan keadaan yang sebenarnya jika pernah mempunyai kebiasaan merokok. ${ }^{6}$ dan begitu juga penelitian yang dilakukan oleh Wahyuni (2019) mendapati bahwa merokok tidak berhubungan dengan kejadian TB MDR. ${ }^{15}$

Terkait faktor pengobatan, terdapat 7 penelitian yang menginvestigasi berbagai kondisi yang berhubungan dengan kejadian TB MDR. Penelitian yang dilakukan oleh Sarwani (2012) mendapati bahwa motivasi berobat yang rendah merupakan faktor risiko terjadinya TB MDR. Individu yang memiliki motivasi berobat rendah akan memiliki risiko 4,2 kali lipat lebih besar untuk mengalami TB MDR daripada individu yang memiliki motivasi berobat yang tinggi. Ini kemungkinan dipengaruhi oleh anggota keluarga dan teman-teman ketika penderita kembali kerumah setelah motivasi/pengobatan awal dan pengobatan wajib bulan pertama. Namun jika kemungkinan motivasi pasien berasal dari lingkungan rumah dan kehadiran anggota keluarga lain, kemungkinan dapat menolong keberlanjutan pengobatan TB. Motivasi dari anggota lain mungkin berpengaruh ke pasien untuk dukung program pengobatan TB secara tuntas. ${ }^{4}$ Hasil ini didukung oleh penelitian Wahyuni (2019) yang juga mendapati bahwa motivasi penderita berhubungan dengan kejadian TB MDR. Penelitian tersebut mendapati bahwa pasien TB dengan motivasi rendah akan memiliki risiko 5,3 kali lipat lebih tinggi untuk mengalami TB MDR. $^{15}$

Penelitian yang dilakukan oleh Sarwani (2012) juga mendapati bahwa ketidakteraturan berobat merupakan faktor risiko terjadinya TB MDR. Pasien TB yang tidak teratur berobat akan memiliki risiko 2,3 kali lipat lebih besar untuk mengalami TB MDR daripada mereka yang teratur berobat, ini disebabkan karena pasien merasa bosan harus minum obat terlalu banyak selama beberapa bulan, dan dapat saja dijadikan beban oleh penderita 
sehingga penderita malas untuk melanjutkan proses pengobatan. ${ }^{4}$ Hasil ini didukung oleh penelitian Mashidayanti (2020) yang juga mendapati bahwa ketidakteraturan berobat berhubungan dengan kejadian TB MDR, dapat terjadi karena timbulnya rasa malas pada penderita, lupa minum obat, serta rasa jenuh, malas dan adanya rasa bosan karena harus minum banyak obat yang dilakukan setiap hari ${ }^{17}$ Penelitian Janan (2019) mendapati bahwa kepatuhan minum obat merupakan salah satu faktor yang mempengaruhi terjadinya TB MDR. Pasien TB yang tidak patuh minum obat akan memiliki risiko 6,7 kali lipat lebih besar untuk mengalami TB MDR daripada pasien yang patuh minum obat. ${ }^{13}$ Hasil tersebut sejalan dengan penelitian Wahyuni (2019) yang juga mendapati bahwa pasien yang tidak patuh minum obat akan memiliki risiko 6,5 kali lipat lebih besar untuk mengalami TB MDR daripada mereka yang patuh minum obat. ${ }^{15}$ Hasil lebih ekstrim didapatkan pada penelitian Maria (2015) yang menyimpulkan bahwa pasien yang tidak patuh minum obat akan memiliki risiko 32 kali lipat lebih besar untuk mengalami TB MDR daripada mereka yang patuh minum obat. ${ }^{5}$

Riwayat pengobatan TB sebelumnya juga menjadi salah satu faktor terjadinya TB MDR. Penelitian Janan (2019) mendapati bahwa individu yang memiliki riwayat pengobatan $\mathrm{TB}$ sebelumnya akan memiliki risiko 5 kali lipat lebih besar untuk mengalami TB MDR daripada mereka yang tidak memiliki riwayat pengobatan TB. ${ }^{13}$ Penelitian Wahyuni (2019) juga mendapati bahwa riwayat pengobatan TB sebelumnya merupakan faktor terpenting terjadinya TB MDR karena individu yang memiliki riwayat TB sebelumnya akan memiliki risiko 31 kali lipat lebih besar untuk mengalami TB MDR daripada mereka yang tidak memiliki riwayat. ${ }^{15}$ Sebagai tambahan, penelitian Nurdin (2020) mendapati bahwa risiko tersebut hanya ditemukan pada pasien TB yang putus obat, disebabkan karena penderita belum memahami pentingnya minum OAT secara teratur. ${ }^{18}$

Penelitian Budi (2018) menjadi satusatunya penelitian yang menginvestigasi komponen lingkungan tempat tinggal sebagai faktor terjadinya TB MDR. Penelitian tersebut mendapati bahwa faktor hunian merupakan faktor yang paling dominan terhadap terjadinya TB MDR. Faktor hunian pada penelitian ini termasuk pencahayaan, kelembaban, kondisi atap, kondisi dinding, dan kondisi lantai rumah. Apabila komponen-komponen tersebut termasuk dalam kategori tidak sehat, maka risiko terjadinya TB MDR akan meningkat 1,57 sampai dengan 4,96 kali lipat. Berhubungan dengan pencahayaan, sinar matahari berperan secara langsung dalam mematikan mikroorganisme yang terdapat dilingkungan rumah, dengan demikian sinar matahari sangat diperlukan di dalam suatu ruangan rumah terutama ruangan tidur, khususnya sinar matahari pagi yang dapat menghambat perkembangan bakteri TB dan bakteri penyakit lainnya. Berhubungan dengan kelembaban, bakteri TB akan tumbuh dengan subur pada lingkungan dengan kelembaban yang tinggi. Air membentuk lebih dari $80 \%$ sel bakteri dan merupakah hal esensial untuk pertumbuhan dan kelangsungan hidup sel bakteri, kelembaban udara yang meningkat merupakan media yang baik untuk bakteri TB berkembang. Berhubungan dengan kondisi atap rumah, dinding, dan lantai kemungkinan disebabkan karena tempat tinggal yang buruk (kurang baik) dapat mendukung terjadinya penularan TB. dinding dan lantai yang sulit dibersihkan atau kadang menyebabkan penumpukan debu, sehingga akan dijadikan media yang baik untuk berkembangbiaknya bakteri TB. ${ }^{10}$

Terdapat 5 laporan penelitian asing yang dianalisis oleh penelitian ini. Kelima penelitian tersebut dilakukan di negaranegara berkembang lain, yaitu Serbia, Ethiopia, Nepal, dan Mali. Penelitian yang dilakukan oleh Stosic (2018) di Serbia mendapati bahwa pendapatan keluarga, tidak berobat, stigma, perasaan sedih, penggunaan obat penenang, dan riwayat 
penyakit paru obstruktif kronis merupakan faktor yang mempengaruhi terjadinya TB MDR. Individu dengan kondisi tersebut akan memiliki risiko 2,79 sampai dengan 4,51 kali lipat lebih besar untuk mengalami TB MDR. ${ }^{11}$ Penelitian Demile (2018) dan Workicho (2017) dilakukan di Etiopia. Beberapa hasil dari penelitian keduanya mendukung satu dengan lainnya, keduanya mendapati bahwa status infeksi HIV merupakan faktor yang mempengaruhi terjadinya TB MDR, ini sebabkan karena penderita dengan infeksi HIV memiliki imunitas yang kurang baik atau menurun sehingga rentan terkena penyakit lainnya termasuk $\mathrm{TB}^{12,9}$ namun beberapa hasil menunjukkan hasil yang bertentangan, yaitu penelitian yang dilakukan oleh Demile (2018) mendapati bahwa riwayat kontak dengan penderita TB MDR merupakan faktor predisposisi yang kuat untuk terjadinya TB MDR, sedangkan usia, jenis kelamin, dan indeks massa tubuh bukan merupakan faktor terkait TB MDR ${ }^{12}$. Hasil berbeda ditunjukkan penelitian Workicho (2017) yang mendapati bahwa usia merupakan salah satu faktor risiko terjadinya TB MDR. Penelitian tersebut juga mendapati bahwa tinggal di rumah tangga dengan hanya satu ruangan dan riwayat pengobatan sebelumnya merupakan faktor yang mempengaruhi terjadinya TB MDR. ${ }^{19}$

Penelitian lain yang dilakukan Maharjan (2017) di Nepal mendapati bahwa faktor yang mempengaruhi terjadinya TB MDR adalah jenis kelamin perempuan saja, alasannya kemungkinan karena perempuan menghabiskan banyak waktu untuk merawat anggota keluarga mereka dengan TB MDR baik di rumah tangga dan rangkaian layanan kesehatan. Alasan lain juga, akibat rendahnya prioritas kesehatan perempuan dalam keluarga dibandingkan dengan laki-laki yang menjadi penghalang dalam mengakses layanan kesehatan yang menyebabkan keterlambatan diagnosis TB. Ini juga bisa jadi karena perempuan lebih prioritaskan anggota keluarga lain untuk mendapatkan gizi yang memadai. Sementara faktor usia, riwayat TB sebelumnya, ras, dan lokasi tempat tinggal tidak mempengaruhi terjadinya TB MDR. ${ }^{8}$ Sementara itu, penelitian Baya (2019) di Mali menunjukkan hasil yang sedikit berbeda. Penelitian tersebut mendapati bahwa faktor yang mempengaruhi terjadinya TB MDR adalah usia $<40$ tahun, riwayat pengobatan TB sebelumnya, kegagalan pengobatan TB, dan riwayat kontak dengan pasien TB. Sedangkan status HIV bukan merupakan faktor terjadinya TB MDR. ${ }^{16}$

Berdasarkan uraian di atas, terlihat bahwa faktor yang mempengaruhi terjadinya TB MDR bisa sangat bervariasi. Beberapa penelitian menunjukkan bahwa suatu kondisi merupakan faktor risiko penting, sementara penelitian di lokasi lain menunjukkan hasil sebaliknya. Perbedaan faktor yang mempengaruhi terjadinya TB MDR di setiap lokasi penelitian ini menunjukkan pentingnya dilakukan identifikasi untuk setiap daerah karena diduga faktor lingkungan, kebiasaan masyarakat, sosioekonomi, dan lain-lain memiliki pengaruh besar dalam patogenesis TB MDR.

\section{SIMPULAN}

Faktor yang mempengaruhi terjadinya TB MDR adalah usia, jenis kelamin, indeks massa tubuh, tingkat pendidikan, riwayat TB MDR pada keluarga, kemudahan akses informasi kesehatan, riwayat menderita TB, riwayat diabetes, kesehatan psikis, merokok, motivasi, ketidakteraturan berobat, kepatuhan minum obat, riwayat menjalani pengobatan TB, faktor hunian, pendapatan keluarga, stigma masyarakat, penggunaan obat penenang, riwayat penyakit paru obstruktif kronis, dan tinggal di rumah tangga dengan hanya satu ruangan.

\section{Konflik Kepentingan}

Penulis menyatakan tidak terdapat konflik kepentingan dalam studi ini. 
DAFTAR PUSTAKA

1. Puri VA, Yovi I FD. Profil Pasien Tuberculosis Multidrug Resistance (TBMDR) di Poliklinik TB-MDR RSUD Arifin Achmad. 2015;1(2):1-17.

2. Indonesia KKR. Pengendalian Penyakit dan Penyehatan Lingkungan Direktorat Pengendalian Penyakit Menular Langsung sub Direktorat Tuberkulosis. tbcindonesia.or.id. doi: 10.1017/CBO9781107415324.004

3. World Health Organization. Global Tuberculosis Report.; 2019.

4. Sarwani D, Nurlaela S, Zahrotul IA. Faktor Risiko Multidrug Resistent Tuberculosis (MDR-TB). KESMAS Jurnal Kesehatan Masyarakat. 2012;8(1):60-66.

5. Maria L. Identifikasi Faktor Risiko Terjadinya TB MDR pada Penderita TB Paru di Wilayah Kerka Kota Madiun. Warta Bhakti Husada Mulia: Jurnal Kesehatan. 2015;2(1):1-5.

6. Widiastuti EN, Subronto YW, Pramono D. Determinan kejadian multi-drug resistant tuberculosis di rumah sakit Dr. Sardjito Yogyakarta. Berita Kedokteran Masyarakat. 2017;33(7): 325-30.

7. Nunkaidah M, Lestari H, Afa JR. Prevalensi Risiko Kejadian Tuberkulosis Multi Drug Resistance (TB-MDR) di Kabupaten Muna Tahun 2013-2015. JIM Kesmas: Jurnal Ilmiah Mahasiswa Kesehatan Masyarakat. 2017;2(6):1-10.

8. Maharjan S, Singh A, Khadka DK, Aryal M. Drug Resistance Pattern in Pulmonary Tuberculosis Patients and Risk Factors Associated with MultiDrug Resistant Tuberculosis. J Tuberc Res. 2017;05(02):106-17.

9. Workicho A, Kassahun W, Alemseged F. Risk factors for multidrug-resistant tuberculosis among tuberculosis patients: A case-control study. Infect Drug Resist. 2017;10:91-6.

10. Budi I, Ardillah Y, Purnama Sari I, Septiawati D. Analisis Faktor Risiko Kejadian penyakit Tuberculosis Bagi Masyarakat Daerah Kumuh Kota Palembang. Jurnal Kesehatan
Lingkungan Indonesia. 2018;17(2): 87-94.

11. Stosic M, Vukovic D, Babic D, et al. Risk factors for multidrug-resistant tuberculosis among tuberculosis patients in Serbia: A case-control study. BMC Public Health. 2018;18(1):1-8.

12. Demile B, Zenebu A, Shewaye H, Xia S, Guadie A. Risk factors associated with multidrug-resistant tuberculosis (MDR-TB) in a tertiary armed force referral and teaching hospital, Ethiopia. BMC Infect Dis. 2018;18(1):1-10.

13. Janan M. Faktor-faktor Risiko yang Berhubungan dengan Peingkatan Prevalensi Kejadian TB MDR di Kabupaten Brebes Tahun 2011-2017. Jurnal Kebijakan Kesehatan Indonesia 2019;8(2):64-70.

14. Ginanjar Y, Astika T, Supriyatna N. Analisis Pengaruh Psikososial dan Faktor Risiko lainnya terhadap Kejadian TB MDR. Bina Generasi Jurnal Kesehatan. 2019;11(1):46-54.

15. Wahyuni T. Faktor-faktor yang Berhubungan dengan Kejadian Multi Drug Resistant Tuberculosis (MDR-TB) (Studi Case Control di Puskesmas Kota Semarang). UNNES Repository. Universitas Negeri Semarang. Published online December 2019.

16. Baya B, Achenbach CJ, Kone B, et al. Clinical risk factors associated with multidrug-resistant tuberculosis (MDR-TB) in Mali. Int J Infect Dis. 2019;81:149-55.

17. Mashidayanti A, Nurlely N, Kartinah N. Faktor Risiko Yang Berpengaruh Pada Kejadian Tuberkulosis dengan Multidrug-Resistant Tuberculosis (MDR-TB) di RSUD Ulin Banjarmasin. J Pharmascience. 2020;7(2):139.

18. Nurdin N. Analisis faktor-faktor determinan Individu terhadap Tuberculosis Multidrug Resistant (TB MDR) di Provinsi Sumatera Selatan. J Kesehat Komunitas. 2020;6(1):63-67.

19. WHO. Consolidated Guidelines on Tuberculosis Treatment, 2016. 